\title{
Vanadium(V) Complexes with Bromo-Substituted Hydrazones: Synthesis, Characterization, X-ray Crystal Structures and Antimicrobial Activity
}

\author{
Cui-Lin Zhang, ${ }^{1}$ Xiao-Yang Qiu ${ }^{1,2, \star}$ and Shu-Juan Liu ${ }^{1}$ \\ ${ }^{1}$ College of Science \& Technology, Ningbo University, Ningbo 315212, P.R. China \\ ${ }^{2}$ State Key Laboratory of Structural Chemistry, Fujian Institute of Research on the Structure of Matter, \\ Chinese Academy of Sciences, Fuzhou, Fujian 350002, P.R. China \\ *Corresponding author: E-mail: xiaoyang_qiu@126.com
}

Received: 05-05-2019

\begin{abstract}
Two new $\mathrm{V}^{\mathrm{V}}$ complexes with the bromo-substituted hydrazones $N^{\prime}$-(3-bromo-2-hydroxybenzylidene)-3-hydroxy-4-methoxybenzohydrazide $\left(\mathrm{H}_{2} \mathrm{~L}^{1}\right)$, $N^{\prime}$-(3-bromo-2-hydroxybenzylidene)-3,5-dimethoxybenzohydrazide $\left(\mathrm{H}_{2} \mathrm{~L}^{2}\right)$, $\left[\mathrm{VOL}^{1}\left(\mathrm{OCH}_{3}\right)\left(\mathrm{CH}_{3} \mathrm{OH}\right)\right](\mathbf{1})$ and $\left[\mathrm{VOL}^{2}\left(\mathrm{OCH}_{3}\right)\left(\mathrm{CH}_{3} \mathrm{OH}\right)\right](2)$, were synthesized and structurally characterized by IR, $\mathrm{UV}$-Vis and ${ }^{1} \mathrm{H}$ NMR spectroscopy, as well as single-crystal X-ray determination. The $\mathrm{V}$ atom in the mononuclear complexes are six-coordinated in octahedral geometry. The free hydrazones and the complexes were studied on their antibacterial activity on S. aureus, B. subtilis, E. coli and P. fluorescence, and antifungal activity on C. albicans and A. niger. The bromo groups of the hydrazone ligands may increase their antibacterial activity.
\end{abstract}

Keywords: Vanadium complex; hydrazone; crystal structure; mononuclear complex; antimicrobial activity

\section{Introduction}

Hydrazones and their complexes have received much interest because of their excellent biological applications in antibacterial, ${ }^{1}$ antifungal, ${ }^{2}$ as well as antitumor. ${ }^{3}$ The compounds with electron-withdrawing groups have been proved to possess increased antimicrobial activity. ${ }^{4}$ Recently, a series of chloro, fluoro, iodo- and bromo-substituted compounds have been assayed for their remarkable antimicrobial activity. ${ }^{5}$ Schiff base vanadium complexes have distinguish antibacterial activity. ${ }^{6}$ In pursuit of new antimicrobial material, we report herein two new bromo-substituted hydrazone compounds $N$ '-(3-bromo-2-hydroxybenzylidene)-3-hydroxy-4-methoxyben-<smiles>COc1ccc(C(=O)N/N=C/c2cccc(Br)c2O)cc1O</smiles>

$\mathrm{H}_{2} \mathrm{~L}^{1}$ zohydrazide $\quad\left(\mathrm{H}_{2} \mathrm{~L}^{1}\right), \quad \mathrm{N}^{\prime}$-(3-bromo-2-hydroxybenzylidene)-3,5-dimethoxybenzohydrazide $\left(\mathrm{H}_{2} \mathrm{~L}^{2}\right)$, and their vanadium $(\mathrm{V})$ complexes, [ $\left.\mathrm{VOL}^{1}\left(\mathrm{OCH}_{3}\right)\left(\mathrm{CH}_{3} \mathrm{OH}\right)\right]$ (1) and $\left[\mathrm{VOL}^{2}\left(\mathrm{OCH}_{3}\right)\left(\mathrm{CH}_{3} \mathrm{OH}\right)\right](2)$, and studied their antimicrobial activities.

\section{Experimental}

\section{1. Materials and Methods}

3-Bromosalicylaldehyde, 3-hydroxy-4-methoxybenzohydrazide, 3,5-dimethoxybenzohydrazide and $\mathrm{VO}$ (a$\mathrm{cac})_{2}$ were obtained from Sigma-Aldrich. The remaining reagents with AR grade were obtained from Xiya Chemi-<smiles>COc1cc(OC)cc(C(=O)N/N=C/c2cccc(Br)c2O)c1</smiles>

$\mathrm{H}_{2} \mathrm{~L}^{2}$ 
cal Reagent Co. Ltd. The hydrazones were prepared by the literature method. ${ }^{7}$ Elemental analyses $(\mathrm{C}, \mathrm{H}, \mathrm{N})$ were determined with a Perkin-Elmer automated model $2400 \mathrm{Se}$ ries II CHNS/O analyzer. The molar conductivity was determined using a DDS-11A conductor device. FT-IR spectra were carried out on a Perkin-Elmer 377 FT-IR spectrometer with $\mathrm{KBr}$ disks. The electronic spectra were performed on a Lambda 35 spectrometer. ${ }^{1} \mathrm{H}$ NMR were carried out on a Bruker $300 \mathrm{MHz}$ instrument. Single crystal X-ray determination was collected on a Bruker APEX II CCD diffractometer.

\section{2. Synthesis of the Hydrazones}

To the $\mathrm{MeOH}$ solution $(30 \mathrm{~mL})$ of 3-bromosalicylaldehyde $(0.01 \mathrm{~mol}, 2.01 \mathrm{~g})$ a $\mathrm{MeOH}$ solution $(20 \mathrm{~mL})$ of 3-hydroxy-4-methoxybenzohydrazide $(0.01 \mathrm{~mol}, 1.82 \mathrm{~g})$ or 3,5-dimethoxybenzohydrazide $(0.01 \mathrm{~mol}, 1.96 \mathrm{~g})$ was added drop wise. The solution was stirred at room temperature for $30 \mathrm{~min}$, and filtered. The filtrate was evaporated to give colorless crystalline product, which were re-crystallized from $\mathrm{MeOH}$ and dried at reduced pressure above anhydrous $\mathrm{CaCl}_{2}$.

For $\mathrm{H}_{2} \mathrm{~L}^{1}$ : Yield $94 \%$. Anal. Calc. for $\mathrm{C}_{15} \mathrm{H}_{13} \mathrm{BrN}_{2} \mathrm{O}_{4}$ : C, 49.3; H, 3.6; N, 7.7. Found: C, 49.5; H, 3.7; N, 7.6\%. IR data $\left(\mathrm{cm}^{-1}\right): 3429,3195,1642,1612$. UV-Vis data $(\mathrm{MeOH}$, $\left.\lambda_{\max }, \mathrm{nm}\right): 225,293,307,325,400 .{ }^{1} \mathrm{H}$ NMR $(300 \mathrm{MHz}$, $d^{6}$-DMSO): $\delta 12.76(\mathrm{~s}, 1 \mathrm{H}, \mathrm{OH}), 12.30(\mathrm{~s}, 1 \mathrm{H}, \mathrm{OH}), 11.27$ (s, 1H, NH), $8.63(\mathrm{~s}, 1 \mathrm{H}, \mathrm{CH}=\mathrm{N}), 7.63(\mathrm{~d}, 1 \mathrm{H}, \mathrm{ArH}), 7.50$ $7.40(\mathrm{~m}, 3 \mathrm{H}, \mathrm{ArH}), 7.13(\mathrm{~d}, 1 \mathrm{H}, \operatorname{ArH}), 6.92(\mathrm{t}, 1 \mathrm{H}, \operatorname{ArH})$, 3.85 (s, $\left.3 \mathrm{H}, \mathrm{OCH}_{3}\right)$. For $\mathrm{H}_{2} \mathrm{~L}^{2}$ : Yield $97 \%$. Anal. Calc. for $\mathrm{C}_{16} \mathrm{H}_{15} \mathrm{BrN}_{2} \mathrm{O}_{4}: \mathrm{C}, 50.68 ; \mathrm{H}, 3.99 ; \mathrm{N}, 7.39$. Found: $\mathrm{C}, 50.53$; $\mathrm{H}, 4.08 ; \mathrm{N}, 7.46 \%$. IR data $\left(\mathrm{cm}^{-1}\right): 3433,3197,1644,1612$. UV-Vis data $\left(\mathrm{MeOH}, \lambda_{\max }, \mathrm{nm}\right): 225,295,307,328,400$. ${ }^{1} \mathrm{H}$ NMR (300 MHz, $d^{6}$-DMSO): $\delta 12.65(\mathrm{~s}, 1 \mathrm{H}, \mathrm{OH}$ ), $11.33(\mathrm{~s}, 1 \mathrm{H}, \mathrm{NH}), 8.63(\mathrm{~s}, 1 \mathrm{H}, \mathrm{CH}=\mathrm{N}), 7.63(\mathrm{~d}, 1 \mathrm{H}, \mathrm{ArH})$, $7.45(\mathrm{~d}, 1 \mathrm{H}, \mathrm{ArH}), 6.92(\mathrm{t}, 1 \mathrm{H}, \mathrm{ArH}), 6.71(\mathrm{~s}, 1 \mathrm{H}, \operatorname{ArH})$, $6.45(\mathrm{~d}, 2 \mathrm{H}, \mathrm{ArH}), 3.84$ (s, 6H, $\left.\mathrm{OCH}_{3}\right)$.

\section{3. Synthesis of the Complexes}

The $\mathrm{MeOH}$ solution $(10 \mathrm{~mL})$ of hydrazones $(0.10$ mmol each) was reacted with the $\mathrm{MeOH}$ solution $(10 \mathrm{~mL})$ of $\mathrm{VO}(\mathrm{acac})_{2}(0.10 \mathrm{mmol}, 26.5 \mathrm{mg})$. The solution was stirred and refluxed for $1 \mathrm{~h}$, and cooled to room temperature. Brown single crystals were generated upon slowly evaporation within 6 days. The crystals were washed with $\mathrm{MeOH}$ and dried at reduced pressure above anhydrous $\mathrm{CaCl}_{2}$.

For 1: Yield $36 \%$. Anal. calc. for $\mathrm{C}_{17} \mathrm{H}_{18} \mathrm{BrN}_{2} \mathrm{O}_{7} \mathrm{~V}$ : C, 41.4; H, 3.7; N, 5.7; found: C, 41.3; H, 3.7; N, 5.6\%. IR data $\left(\mathrm{cm}^{-1}\right)$ : $3454(\mathrm{w}), 1603(\mathrm{~s}), 958(\mathrm{~m}) . \mathrm{UV}-\mathrm{Vis}$ data $(\mathrm{MeOH}$, $\left.\lambda_{\max }, \mathrm{nm}\right): 272,335 .{ }^{1} \mathrm{H}$ NMR $\left(300 \mathrm{MHz}, d^{6}\right.$-DMSO): $\delta$ $12.71(\mathrm{~s}, 1 \mathrm{H}, \mathrm{OH}), 12.20(\mathrm{~s}, 1 \mathrm{H}, \mathrm{OH}), 9.39$ (s, 1H, $\mathrm{ArH})$, $8.56(\mathrm{~s}, 1 \mathrm{H}, \mathrm{CH}=\mathrm{N}), 7.61(\mathrm{q}, 1 \mathrm{H}, \mathrm{ArH}), 7.51-7.41(\mathrm{~m}, 2 \mathrm{H}$, $\operatorname{ArH}), 7.08(\mathrm{~d}, 1 \mathrm{H}, \operatorname{Ar} H), 6.91(\mathrm{t}, 1 \mathrm{H}, \operatorname{ArH}), 3.86(\mathrm{~s}, 3 \mathrm{H}$, $\left.\mathrm{OCH}_{3}\right), 3.33\left(\mathrm{~s}, 6 \mathrm{H}, \mathrm{CH}_{3} \mathrm{OH}\right.$ and $\left.\mathrm{OCH}_{3}\right) . \Lambda_{\mathrm{M}}\left(10^{-3} \mathrm{M}\right.$ in

Table 1. Crystallographic and refinement data for complexes $\mathbf{1}$ and $\mathbf{2}$

\begin{tabular}{|c|c|c|c|}
\hline Complex & $\mathrm{H}_{2} \mathrm{~L}^{1}$ & 1 & 2 \\
\hline Formula & $\mathrm{C}_{15} \mathrm{H}_{13} \mathrm{BrN}_{2} \mathrm{O}_{4}$ & $\mathrm{C}_{17} \mathrm{H}_{18} \mathrm{BrN}_{2} \mathrm{O}_{7} \mathrm{~V}$ & $\mathrm{C}_{18} \mathrm{H}_{20} \mathrm{BrN}_{2} \mathrm{O}_{7} \mathrm{~V}$ \\
\hline Formula weight & 365.18 & 493.18 & 507.21 \\
\hline$T(\mathrm{~K})$ & $298(2)$ & $298(2)$ & $298(2)$ \\
\hline Crystal system & Monoclinic & Triclinic & Monoclinic \\
\hline Space group & $P 2_{1} / c$ & $P-1$ & $P 2_{1} / n$ \\
\hline$a(\AA)$ & $17.2603(13)$ & $7.6101(9)$ & $13.5326(10)$ \\
\hline$b(\AA)$ & $7.2902(12)$ & $10.3404(13)$ & $9.3050(7)$ \\
\hline$c(\AA)$ & $12.1706(19)$ & $13.1269(16)$ & $16.1808(13)$ \\
\hline$\alpha\left({ }^{\circ}\right)$ & 90 & $81.517(1)$ & 90 \\
\hline$\beta\left({ }^{\circ}\right)$ & $104.431(1)$ & $75.965(1)$ & $94.621(1)$ \\
\hline$\gamma\left({ }^{\circ}\right)$ & 90 & $68.939(1)$ & 90 \\
\hline$V\left(\AA^{3}\right)$ & $1483.1(4)$ & $933.1(2)$ & $2030.9(3)$ \\
\hline$Z$ & 4 & 2 & 4 \\
\hline$D_{\text {calc }}\left(\mathrm{g} \mathrm{cm}^{-3}\right)$ & 1.635 & 1.755 & 1.659 \\
\hline$\mu(\mathrm{Mo} \mathrm{K} \alpha)\left(\mathrm{mm}^{-1}\right)$ & 2.791 & 2.716 & 2.499 \\
\hline$F(000)$ & 736 & 496 & 1024 \\
\hline Measured reflections & 8532 & 8761 & 18003 \\
\hline Unique reflections & 2764 & 3455 & 3606 \\
\hline Observed reflections $(I \geq 2 s(I))$ & 1896 & 2906 & 2900 \\
\hline Parameters & 205 & 260 & 269 \\
\hline Restraints & 1 & 1 & 1 \\
\hline Goodness of fit on $F^{2}$ & 1.025 & 1.030 & 1.039 \\
\hline$R_{1}, w R_{2}[I \geq 2 \sigma(I)]^{a}$ & $0.0437,0.1036$ & $0.0285,0.0679$ & $0.0345,0.0776$ \\
\hline$R_{1}, w R_{2}(\text { all data })^{a}$ & $0.0717,0.1159$ & $0.0378,0.0721$ & $0.0498,0.0857$ \\
\hline
\end{tabular}


acetonitrile): $41 \Omega^{-1} \mathrm{~cm}^{2} \mathrm{~mol}^{-1}$. For 2: Yield $41 \%$. Anal. calc. for $\mathrm{C}_{18} \mathrm{H}_{20} \mathrm{BrN}_{2} \mathrm{O}_{7} \mathrm{~V}$ : C, 42.62; $\mathrm{H}, 3.97 ; \mathrm{N}, 5.52$; found: C, 42.73; H, 3.89; N, 5.61\%. IR data $\left(\mathrm{cm}^{-1}\right): 3450(\mathrm{w}), 1602$ (s), $953(\mathrm{~m})$. UV-Vis data $\left(\mathrm{MeOH}, \lambda_{\max }, \mathrm{nm}\right): 275,323 .{ }^{1} \mathrm{H}$ NMR (300 MHz, d6-DMSO): $\delta 12.56(\mathrm{~s}, 1 \mathrm{H}, \mathrm{OH}), 9.30$ (s, $1 \mathrm{H}, \operatorname{ArH}), 8.59(\mathrm{~s}, 1 \mathrm{H}, \mathrm{CH}=\mathrm{N}), 7.66(\mathrm{~d}, 1 \mathrm{H}, \operatorname{ArH}), 7.53$ (d, $1 \mathrm{H}, \mathrm{ArH}), 7.17-6.91(\mathrm{~m}, 2 \mathrm{H}, \mathrm{ArH}), 6.70$ (s, 1H, ArH), 3.84 $\left(\mathrm{s}, 3 \mathrm{H}, \mathrm{OCH}_{3}\right), 3.78\left(\mathrm{~s}, 3 \mathrm{H}, \mathrm{OCH}_{3}\right), 3.38\left(\mathrm{~s}, 6 \mathrm{H}, \mathrm{CH}_{3} \mathrm{OH}\right.$ and $\left.\mathrm{OCH}_{3}\right) . \Lambda_{\mathrm{M}}\left(10^{-3} \mathrm{M}\right.$ in acetonitrile $): 32 \Omega^{-1} \mathrm{~cm}^{2} \mathrm{~mol}^{-1}$.

\section{4. X-ray Crystallography}

Single crystal X-ray determination was performed on a Bruker APEX II CCD area diffractometer with Mo Ka radiation at $0.71073 \AA$. The data were reduced with the program SAINT, ${ }^{8}$ and corrected by multi-scan using the program SADABS. ${ }^{9}$ The vanadium complexes were solved readily by direct method. The complexes were refined by the full-matrix least-squares method against $F^{2}$ using the program SHELXTL. ${ }^{10}$ The non-H atoms were anisotropically refined. The $\mathrm{H}$ atoms of the methanol molecules were assigned from the difference Fourier maps, and isotropically refined with $d_{\mathrm{O}-\mathrm{H}}$ restrained to $0.85(1) \AA$. The other $\mathrm{H}$ atoms were in calculated geometrical positions. The crystallographic data and refinement parameters are summarized in Table 1.

\section{5. Antimicrobial Study}

The activities against B. subtilis, S. aureus, E. coli, and $P$. fluorescence of the compounds were assayed with $\mathrm{MH}$ (Mueller-Hinton) medium. The activities against C. albicans and $A$. niger of the compounds were assayed with RPMI-1640 medium. The dye MTT was used in the determination of the MIC values by a colorimetric method. ${ }^{11} \mathrm{~A}$ specified quantity of the medium with the tested compound was poured into micro-titration plates. Suspension of the microorganism containing $1.0 \times 10^{5} \mathrm{cfu} \mathrm{mL}^{-1}$ was applied to micro-titration plates with the compounds in DMSO to be tested and incubated at $37^{\circ} \mathrm{C}$ for $24 \mathrm{~h}$ and $48 \mathrm{~h}$ for bacteria and fungi, respectively. The MIC values were visually determined on each of the microtitration plates, Phosphate buffered saline $\left(50 \mu \mathrm{L}, 0.01 \mathrm{~mol} \mathrm{~L}^{-1}, \mathrm{pH}=7.4\right)$ containing 2 $\mathrm{mg}$ of $\mathrm{MTT} \cdot \mathrm{mL}^{-1}$ was poured into the well. Incubation was continued for $4-5 \mathrm{~h}$ at room temperature. The content of the well was removed and isopropanol $(100 \mu \mathrm{L})$ containing $5 \% 1 \mathrm{~mol} \mathrm{~L}^{-1} \mathrm{HCl}$ was added to extract the dye. The optical density was determied with a micro-plate reader at $550 \mathrm{~nm}$ after $12 \mathrm{~h}$ of incubation at room temperature.

\section{Results and Discussion}

\section{1. Chemistry}

The hydrazones $\mathrm{H}_{2} \mathrm{~L}^{1}$ and $\mathrm{H}_{2} \mathrm{~L}^{2}$ were synthesized by the reaction of 3-bromosalicylaldehyde and 3-hydroxy- 4-methoxybenzohydrazide and 3,5-dimethoxybenzohydrazide, respectively in ethanol. The vanadium complexes were synthesized by the reaction of the hydrazones $\mathrm{H}_{2} \mathrm{~L}^{1}$ and $\mathrm{H}_{2} \mathrm{~L}^{2}$ with $\mathrm{VO}(\mathrm{acac})_{2}$ in $\mathrm{MeOH}$ followed by re-crystallization. Elemental analyses $(\mathrm{C}, \mathrm{H}, \mathrm{N})$ of the complexes are in accordance with the results of single-crystal X-ray analysis.

\section{2. Spectroscopic Studies}

In the spectra of the compounds, the broad and weak absorptions at $3400-3500 \mathrm{~cm}^{-1}$ can be attributed to the $v(\mathrm{O}-\mathrm{H})$. The sharp and weak bands of $\mathrm{H}_{2} \mathrm{~L}$ located at $c a$. $3195 \mathrm{~cm}^{-1}$ can be attributed to the $v(\mathrm{~N}-\mathrm{H})$. The strong absorption at $1643 \mathrm{~cm}^{-1}$ of $\mathrm{H}_{2} \mathrm{~L}$ are generated by $v(\mathrm{C}=\mathrm{O})$, whereas the typical bands at $1612 \mathrm{~cm}^{-1}$ are the $v(\mathrm{C}=\mathrm{N})$. The absence of the $v(\mathrm{C}=\mathrm{O})$ and $v(\mathrm{~N}-\mathrm{H})$ in the spectra of the complexes, suggests that the hydrazone ligands are enolized during the coordination. The intense bands at $1602 \mathrm{~cm}^{-1}$ of the complexes are due to the $v(\mathrm{C}=\mathrm{N})$. The characteristic $v(\mathrm{~V}=\mathrm{O})$ at $955 \mathrm{~cm}^{-1}$ for the complexes can be obviously identified. ${ }^{12}$

The bands in the UV-Vis spectra of the compounds at $320-340 \mathrm{~nm}$ are attributed to the intra-ligand $\pi \rightarrow \pi^{*}$ absorption. The lowest energy transition bands of the complexes are located at $400 \mathrm{~nm}$, which can be attributed to LMCT transition. The LMCT and to some extent $\pi \rightarrow \pi^{\star}$ bands observed at $275 \mathrm{~nm}$ for complexes $\mathbf{1}$ and $\mathbf{2}$ are attributed to the $\mathrm{O}$ donor atoms bound to $\mathrm{V}$ atoms. ${ }^{12}$

The ${ }^{1} \mathrm{H}$ NMR spectra of the free hydrazones $\mathrm{H}_{2} \mathrm{~L}^{1}$ and $\mathrm{H}_{2} \mathrm{~L}^{2}$ exhibit $\mathrm{OH}$ (phenolic) resonances at 12.76 and $12.30 \mathrm{ppm}$, and $12.65 \mathrm{ppm}$, respectively. Signals for one $\mathrm{CH}$ proton at $8.63 \mathrm{ppm}$, and one $\mathrm{NH}$ proton at $11.27 \mathrm{ppm}$ for $\mathrm{H}_{2} \mathrm{~L}^{1}$, and signals for one $\mathrm{CH}=\mathrm{N}$ proton at $8.63 \mathrm{ppm}$, and one $\mathrm{NH}$ proton at $11.33 \mathrm{ppm}$ for $\mathrm{H}_{2} \mathrm{~L}^{2}$. Signals for aromatic protons are found in the 7.63-6.45 ppm range. Signals for methoxy protons are found at about 3.84-3.85 ppm. The ${ }^{1} \mathrm{H}$ NMR spectrum of complex 1 exhibits two sets of proton signals at 12.71 and $12.20 \mathrm{ppm}$, and that of complex 2 exhibits one proton signal at $12.56 \mathrm{ppm}$. There are no $\mathrm{NH}$ signals observed, indicating the coordination of the hydrazones through enolate form. The aromatic protons appear in the range 9.39-6.70 ppm. In addition, there exhibits bands at 3.33-3.38 ppm due to the coordinated methoxide and methanol ligands. The $\mathrm{CH}=\mathrm{N}$ proton signals are observed at $8.56 \mathrm{ppm}$ for $\mathbf{1}$ and $8.59 \mathrm{ppm}$ for 2 .

\section{3. Structure Description of $\mathrm{H}_{2} \mathrm{~L}^{1}$}

The molecular structure of $\mathrm{H}_{2} \mathrm{~L}^{1}$ is depicted in Figure 1. The compound adopts $E$ configuration about the $\mathrm{CH}=\mathrm{N}$ unit. The methylidene bond C7-N1 (1.281(5) A) is within typical double bond. The distance of C8-N2 bond (1.356(4) $\AA$ ) is shorter, and the distance of C8-O2 bond (1.230(4) $\AA$ ) is longer than usual, suggests the conjugation effects in the hydrazone molecule. The bond values are within normal ranges. ${ }^{4 a}$ The two aromatic rings form a dihedral angle of 


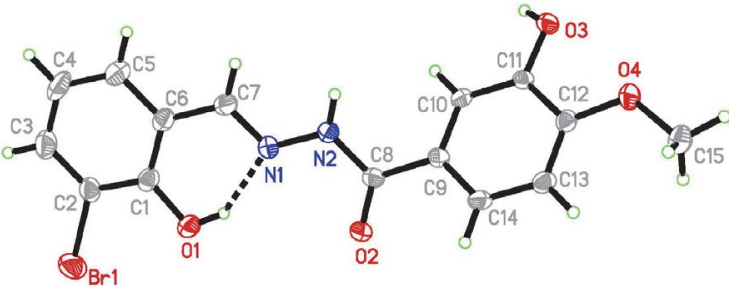

Figure 1. A perspective view of $\mathrm{H}_{2} \mathrm{~L}^{1}$ with the atom labeling scheme. Thermal ellipsoids are drawn at the $30 \%$ probability level. Hydrogen bond is indicated by a dotted line.

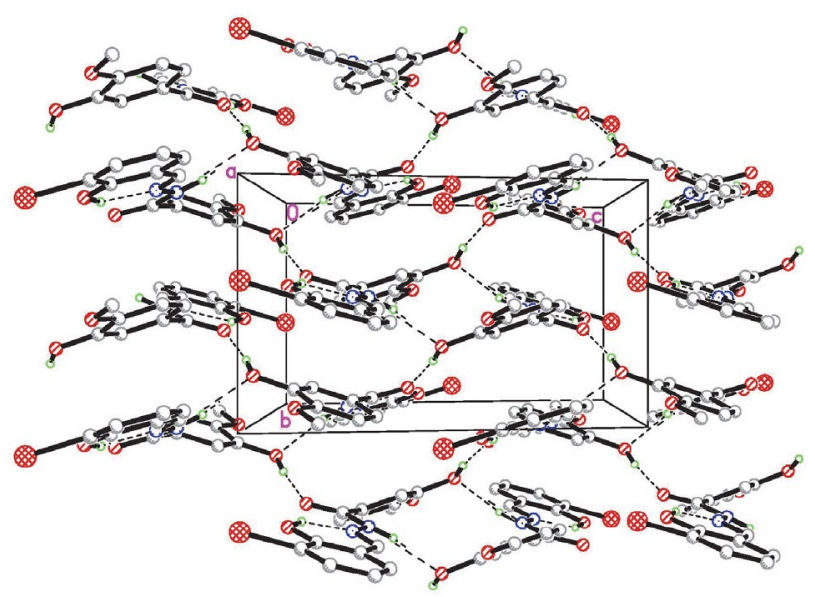

Figure 2. Molecular packing structure of $\mathrm{H}_{2} \mathrm{~L}^{1}$, with hydrogen bonds indicated by dotted lines.

$39.0(3)^{\circ}$. Crystal structure of the compound is stabilized by intermolecular hydrogen bonds (Table 3, Figure 2).

\section{4. Structure Description of the Vanadium Complexes}

The molecular structures of the vanadium complexes are depicted in Figures 3 and 4, respectively. Selected bond lengths and angles are listed in Table 2. The V atoms are in distorted octahedral geometry with the hydrazone ligand coordinated in a meridional fashion. The hydrazones form five- and six-membered chelate rings with the $\mathrm{V}$ atoms. The chelate angles are $74.0-74.2^{\circ}$ and $82.8-83.5^{\circ}$, respectively, which are not uncommon for this type of ligand systems. ${ }^{13}$ The hydrazone ligand lies in a plane with one hydroxylato ligand which lies trans to the hydrazone imino $\mathrm{N}$ atom. One $\mathrm{O}$ atom of the $\mathrm{MeOH}$ ligand trans to the oxido group completes the octahedral geometry at rather elongated distances of $2.40-2.44 \AA$. The displacements of the $\mathrm{V}$ atoms from the planes defined by the four equatorial donors toward the apical oxido atoms are 0.32$0.33 \AA$. The hydrazones coordinate in their doubly deprotonated enolate form which is consistent with the observed O2-C8 and N2-C8 bond lengths of about 1.29-1.32 $\AA$. This agrees with reported metal complexes containing the enolate form of this ligand type. ${ }^{14}$

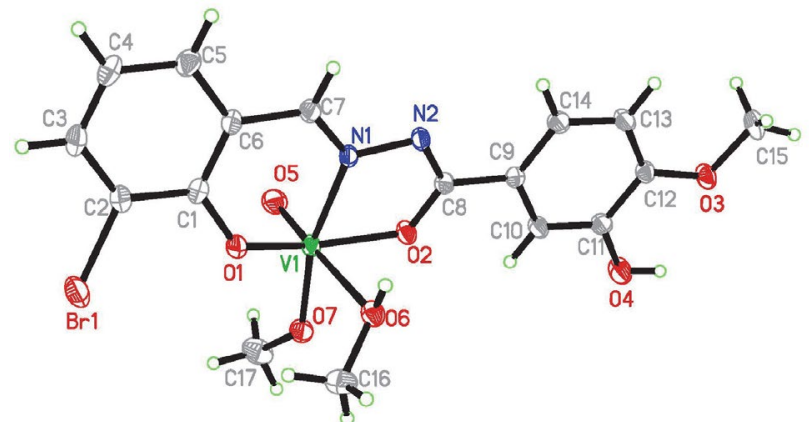

Figure 3. A perspective view of complex 1 with the atom labeling scheme. Thermal ellipsoids are drawn at the $30 \%$ probability level.

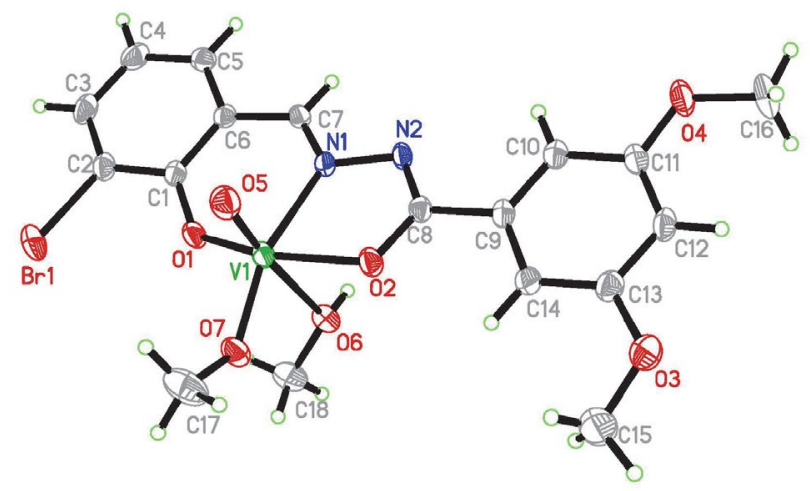

Figure 4. A perspective view of complex 2 with the atom labeling scheme. Thermal ellipsoids are drawn at the $30 \%$ probability level.

In the crystal structure of complex $\mathbf{1}$, the molecules are linked by intermolecular hydrogen bonds (Table 3), leading to the formation of 3D network (Figure 5). In the crystal structure of complex 2 , the molecules are linked by hydrogen bonds (Table 3), leading to the formation of dimers (Figure 6).

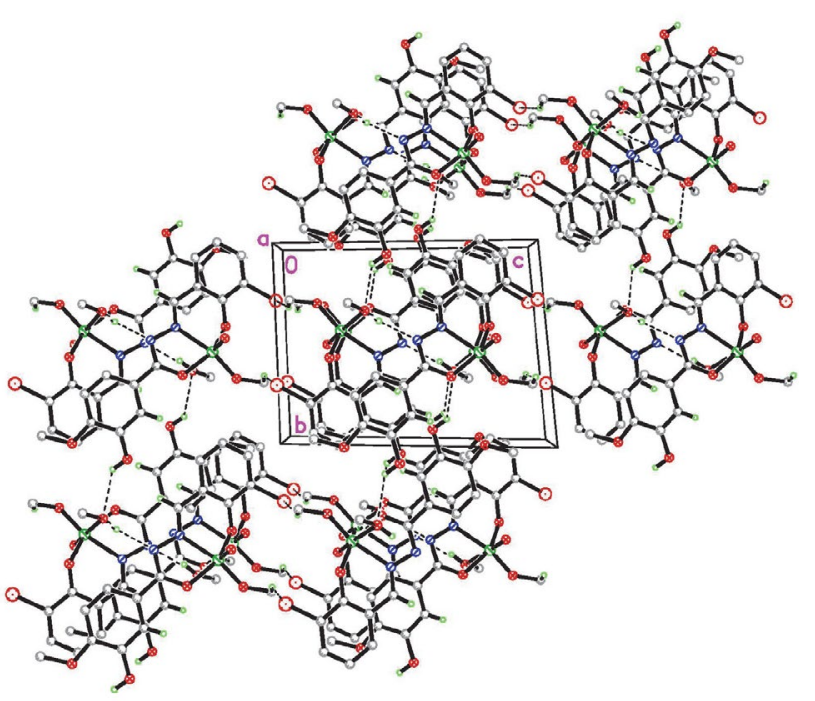

Figure 5.Crystal structure of complex 1, with hydrogen bonds indicated by dotted lines. 


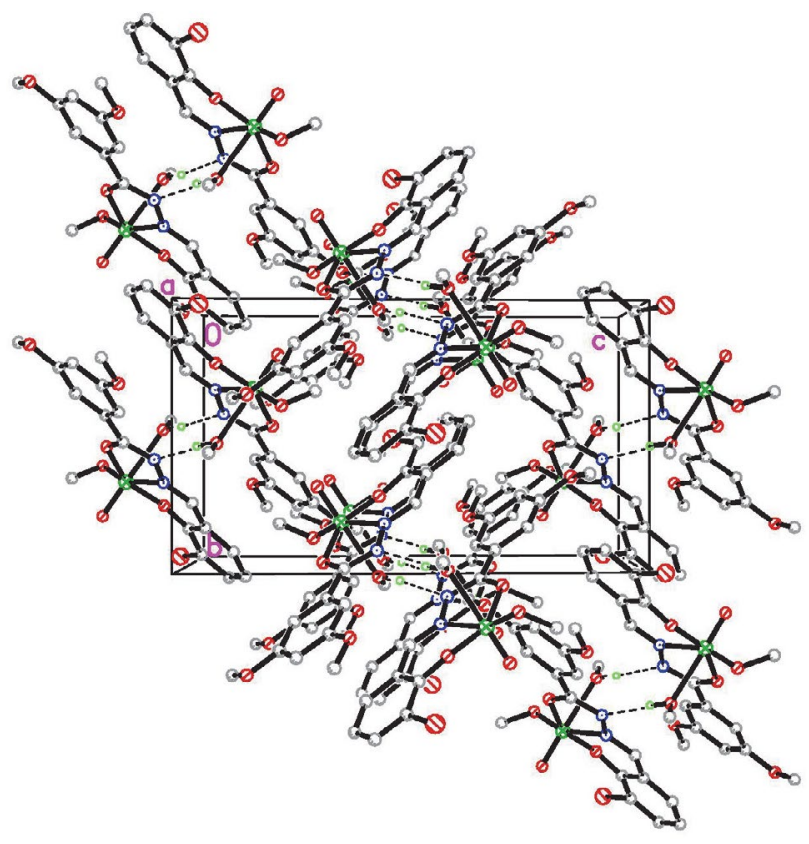

Figure 6.Crystal structure of complex 2, with hydrogen bonds indicated by dotted lines.
Table 2. Selected bond distances $(\AA)$ and angles $\left(^{\circ}\right)$ for the complexes

\begin{tabular}{lll}
\hline & $\mathbf{1}$ & $\mathbf{2}$ \\
\hline V1-O1 & $1.8676(16)$ & $1.8594(18)$ \\
V1-O2 & $1.9309(15)$ & $1.9445(18)$ \\
V1-O5 & $1.5831(17)$ & $1.581(2)$ \\
V1-O6 & $2.4343(17)$ & $2.407(2)$ \\
V1-O7 & $1.7698(16)$ & $1.7559(19)$ \\
V1-N1 & $2.1330(18)$ & $2.129(2)$ \\
O5-V1-O7 & $102.51(8)$ & $103.79(11)$ \\
O5-V1-O1 & $99.01(9)$ & $99.96(10)$ \\
O7-V1-O1 & $98.66(7)$ & $99.68(9)$ \\
O5-V1-O2 & $100.53(8)$ & $97.85(10)$ \\
O7-V1-O2 & $97.74(7)$ & $96.05(9)$ \\
O1-V1-O2 & $151.03(7)$ & $152.61(9)$ \\
O5-V1-N1 & $96.04(8)$ & $96.01(10)$ \\
O7-V1-N1 & $160.86(7)$ & $159.01(9)$ \\
O1-V1-N1 & $82.88(7)$ & $83.45(8)$ \\
O2-V1-N1 & $74.00(6)$ & $74.12(8)$ \\
O5-V1-O6 & $177.35(8)$ & $174.54(9)$ \\
O7-V1-O6 & $80.15(7)$ & $80.79(8)$ \\
O1-V1-O6 & $80.48(7)$ & $82.00(8)$ \\
O2-V1-O6 & $79.01(6)$ & $78.55(8)$ \\
N1-V1-O6 & $81.32(6)$ & $79.10(7)$ \\
\hline
\end{tabular}

Table 3. Hydrogen bond values for the compounds

\begin{tabular}{llllc}
\hline $\boldsymbol{D}-\mathrm{H} \cdots \boldsymbol{A}$ & $\boldsymbol{d}(\boldsymbol{D}-\boldsymbol{H})$ & $\boldsymbol{d}(\mathbf{H} \cdots \boldsymbol{A})$ & $\boldsymbol{d}(\boldsymbol{D} \cdots \boldsymbol{A})$ & Angle $(\boldsymbol{D}-\mathbf{H} \cdots \boldsymbol{A})$ \\
\hline $\mathrm{H}_{2} \mathrm{~L}^{1}$ & & & & \\
$\mathrm{~N} 3-\mathrm{H} 2 \cdots \mathrm{O}^{\mathrm{i}}$ & $0.90(1)$ & $2.00(1)$ & $2.885(3)$ & $169(4)$ \\
$\mathrm{O} 3-\mathrm{H} 3 \cdots \mathrm{O} 2^{\mathrm{ii}}$ & 0.82 & 1.84 & $2.654(3)$ & $172(4)$ \\
$\mathrm{O} 1-\mathrm{H} 1 \cdots \mathrm{N} 1$ & 0.82 & 1.87 & $2.577(4)$ & $144(4)$ \\
$\mathbf{1}$ & & & & \\
$\mathrm{O} 4-\mathrm{H} 4 \cdots \mathrm{O} 6^{i i i}$ & 0.82 & 2.39 & $3.009(2)$ & $133(5)$ \\
$\mathrm{O} 6-\mathrm{H} 6 \cdots \mathrm{N} 2$ & $0.84(1)$ & $2.06(1)$ & $2.893(2)$ & $171(3)$ \\
$\mathrm{C} 7-\mathrm{H} 7 \cdots \mathrm{O} 4^{\text {iv }}$ & 0.93 & 2.58 & $3.381(2)$ & $144(5)$ \\
$\mathbf{2}$ & & & & \\
$\mathrm{O}^{\mathrm{O}}-\mathrm{H} 6 \cdots \mathrm{N} 2^{\mathrm{v}}$ & $0.85(1)$ & $2.07(1)$ & $2.911(3)$ & $172(4)$ \\
\hline
\end{tabular}

Symmetry codes: (i) $1-x, 1-y, 1-z$; (ii) $x, 1 / 2-y, 1 / 2+z$; (iii) $x, 1+y, z$; (iv) $x,-1+y, z$; (v) $1-x, 1-y,-z$.

\section{5. Antimicrobial Activity}

The free hydrazones and the complexes were assayed for antibacterial activities against two Gram (+) bacterial strains (B. subtilis and S. aureus) and two Gram (-) bacterial strains (E. coli and P. fluorescence) by MTT method. The MIC (minimum inhibitory concentration, $\mu \mathrm{g} \mathrm{mL}^{-1}$ ) values are given in Table 4. Penicillin G was assayed as the reference drug. Both the free hydrazones show medium activity against $B$. subtilis and $S$. aureus, weak activity against $P$. fluorescence, and no activity against $E$. coli. The two vanadi$\mathrm{um}(\mathrm{V})$ complexes in this work have superior activity against the bacteria than the free hydrazones. The complexes have excellent activity against $B$. subtilis, $S$. aureus and $E$. coli which are comparable to Penicillin G. Complex $\mathbf{1}$ has no activity against $P$. fluoresence, while complex $\mathbf{2}$ has weak activity. Both complexes have no activity on the fungal strains Aspergillus niger and Candida albicans.
Table 4. Antimicrobial results with MIC $\left(\mu \mathrm{g} \mathrm{mL}^{-1}\right)$

\begin{tabular}{lcccc}
\hline & B. subtilis & S. aureus & E. coli & P. fluorescence \\
\hline $\mathrm{H}_{2} \mathrm{~L}^{1}$ & 37.5 & 18.8 & 75 & $>150$ \\
$\mathrm{H}_{2} \mathrm{~L}^{2}$ & 18.8 & 18.8 & 75 & $>150$ \\
$\mathbf{1}$ & 4.6 & 9.4 & 9.4 & $>150$ \\
$\mathbf{2}$ & 2.3 & 9.4 & 9.4 & 75 \\
Penicillin G & 2.3 & 4.7 & $>150$ & $>150$ \\
\hline
\end{tabular}

\section{Supplementary Data}

CCDC $1913947\left(\mathrm{H}_{2} \mathrm{~L}^{1}\right), 1913948$ (1) and 1913949 (2) contain the supplementary crystallographic data for the compounds. The data can be obtained free of charge via http://www.ccdc.cam.ac.uk/conts/retrieving.html, or from the Cambridge Crystallographic Data Centre, 12 
Union Road, Cambridge CB2 1EZ, UK; fax: $(+44) 1223-$ 336-033; or e-mail: deposit@ccdc.cam.ac.uk.

\section{Acknowledgments}

This work was financially supported by K.C. Wong Magna Fund in Ningbo University, Ningbo Natural Science Fund (Project No. 201701HJ-B01019), State Key Laboratory Development Fund of Structural Chemistry and Ningbo Education Research Project (Project No. 2017YZD001).

\section{References}

1. (a) K. Pyta, A. Janas, M. Szukowska, P. Pecyna, M. Jaworska, M. Gajecka, F. Bartl, P. Przybylski, Eur. J. Med. Chem. 2019, 167, 96-104;DOI:10.1016/j.ejmech.2019.02.009

(b) R. Fekri, M. Salehi, A. Asadi, M. Kubicki, Inorg. Chim. Acta 2019, 484, 245-254; DOI:10.1016/j.ica.2018.09.022

(c) H. Y. Qian, Inorg. Nano-Met. Chem. 2018, 48, 461-466; DOI:10.1080/24701556.2019.1569689

(d) H. Y. Qian, Russ. J. Coord. Chem. 2017, 43, 780-786. DOI: $10.1134 /$ S1070328417110070

2. (a) D. A. Megger, K. Rosowski, C. Radunsky, J. Kosters, B. Sitek, J. Muller, Dalton Trans. 2017, 46, 4759-4767;

DOI:10.1039/C6DT04613D

(b) N. R. Palepu, J. R. Premkumar, A. K. Verma, K. Bhattacharjee, S. R. Joshi, S. Forbes, Y. Mozharivskyj, K. M. Rao, Arabian J. Chem. 2018, 11, 714-728.

DOI:10.1016/j.arabjc.2015.10.011

3. (a) Y.-C. Liu, H.-L. Wang, S.-F. Tang, Z.-F. Chen, H. Liang, Anticancer Res. 2014, 34, 6034-6035;

(b) A. Erguc, M. D. Altintop, O. Atli, B. Sever, G. Iscan, G. Gormus, A. Ozdemir, Lett. Drug Des. Discov. 2018, 15, 193-202.

4. (a) M. Zhang, D.-M. Xian, H.-H. Li, J.-C. Zhang, Z.-L. You, Aust. J. Chem. 2012, 65, 343-350;

DOI:10.1071/CH11424

(b) L. Shi, H.-M. Ge, S.-H. Tan, H.-Q. Li, Y.-C. Song, H.-L. Zhu, R.-X. Tan, Eur. J. Med. Chem. 2007, 42, 558-564.

DOI:10.1016/j.ejmech.2006.11.010

5. N. P. Rai, V. K. Narayanaswamy, T. Govender, B. K. Manuprasad, S. Shashikanth, P. N. Arunachalam, Eur. J. Med. Chem. 2010, 45, 2677-2682.

DOI:10.1016/j.ejmech.2010.02.021
6. (a) L.-H. Wang, X.-Y. Qiu, S.-J. Liu, J. Coord. Chem. 2019, DOI:10.1080/00958972.2019.1590561

(b) X. W. Zhu, Russ. J. Coord. Chem. 2018, 44, 335-339; DOI:10.3103/S1068367418040213

(c) Z. H. Chohan, S. H. Sumrra, M. H. Youssoufi, T. B. Hadda, Eur. J. Med. Chem. 2010, 45, 2739-2747;

DOI:10.1016/j.ejmech.2010.02.053

(d) O. Taheri, M. Behzad, A. Ghaffari, M. Kubicki, G. Dutkiewicz, A. Bezaatpour, H. Nazari, A. Khaleghian, A. Mohammadi, M. Salehi, Transition Met. Chem. 2014, 39, 253-259.

DOI:10.1007/s11243-014-9798-9

7. D. Qu, F. Niu, X. Zhao, K.-X. Yan, Y.-T. Ye, J. Wang, M. Zhang, Z. You, Bioorg. Med. Chem. 2015, 23, 1944-1949.

DOI:10.1016/j.bmc.2015.03.036

8. Bruker, SMART (Version 5.625) and SAINT (Version 6.01). Bruker AXS Inc., Madison, Wisconsin, USA, 2007.

9. G. M. Sheldrick, SADABS. Program for Empirical Absorption Correction of Area Detector, University of Göttingen, Germany, 1996.

10. G. M. Sheldrick, SHELXTL V5.1 Software Reference Manual, Bruker AXS, Inc., Madison, Wisconsin, USA, 1997.

11. J. Meletiadis, J. F. G. M. Meis, J. W. Mouton, J. P. Donnelly, P. E. Verweij, J. Clin. Microbiol. 2000, 38, 2949-2954.

12. A. Sarkar, S. Pal, Polyhedron 2007, 26, 1205-1210. DOI:10.1016/j.poly.2006.10.012

13. (a) D.-L. Peng, Transit. Met. Chem. 2016, 41, 843-848; DOI:10.1007/s11243-016-0086-8

(b) X. W. Zhu, Russ. J. Coord. Chem. 2018, 44, 421-424. DOI:10.1134/S1070328418070084

14. (a) D. L. Peng, Russ. J. Coord. Chem. 2017, 43, 404-410; DOI:10.1134/S1070328417060045

(b) Y. Li, L. Xu, M. Duan, J. Wu, Y. Wang, K. Dong, M. Han, Z. You, Inorg. Chem. Commun. 2019, 105, 212-216; DOI:10.1016/j.inoche.2019.05.011

(c) S. Guo, N. Sun, Y. Ding, A. Li, Y. Jiang, W. Zhai, Z. Li, D. Qu, Z. You, Z. Anorg. Allg. Chem. 2018, 644, 1172-1176; DOI:10.1002/zaac.201800060

(d) L.-Y. He, X.-Y. Qiu, J.-Y. Cheng, S.-H. Liu, S.-M. Wu, Polyhedron 2018, 156, 105-110; DOI:10.1016/j.poly.2018.09.017 (e) S.-J. Li, K. Li, X.-J. Yao, X.-Y. Qiu, J. Coord. Chem. 2015, 68, 2846-2857; DOI:10.1080/00958972.2015.1056171

(f) X.-Y. Qiu, Chin. J. Inorg. Chem. 2014, 30, 1667-1672;

(g) M. Liang, N. Sun, D.-H. Zou, Acta Chim. Slov. 2018, 65, 964-969; DOI:10.17344/acsi.2018.4625

(f) Z.-Q. Han, S. Han, Y. Wang, Acta Chim. Slov. 2016, 63, 200-203; (g) S.-S. Qian, X. Zhao, J. Wang, Z. You, Acta Chim. Slov. 2015, 62, 828-833. 


\section{Povzetek}

Sintetizirali smo dva nova $\mathrm{V}^{\mathrm{V}}$ kompleksa z bromo-substituiranima hidrazonoma, N'-(3-bromo-2-hidroksibenziliden)-3-hidroksi-4-metoksibenzohidrazidom $\left(\mathrm{H}_{2} \mathrm{~L}^{1}\right)$ in $N^{\prime}$-(3-bromo-2-hidroksibenziliden)-3,5-dimetoksibenzohidrazidom $\left(\mathrm{H}_{2} \mathrm{~L}^{2}\right)$, $\left[\mathrm{VOL}^{1}\left(\mathrm{OCH}_{3}\right)\left(\mathrm{CH}_{3} \mathrm{OH}\right)\right](\mathbf{1})$ in $\left[\mathrm{VOL}^{2}\left(\mathrm{OCH}_{3}\right)\left(\mathrm{CH}_{3} \mathrm{OH}\right)\right](2)$ ter ju okarakterizirali $\mathrm{z}$ IR, UV-Vis in ${ }^{1} \mathrm{H}$ NMR spektroskopijo ter $\mathrm{z}$ monokristalno rentgensko analizo. $\mathrm{V}$ enojedrnih kompleksih je vanadijev atom oktaedrično koordiniran. Prostima hidrazonoma in kompleksoma smo določili antibakterijsko aktivnost na S. aureus, B. subtilis, E. coli in P. fluorescence ter antimikotično aktivnost na C. albicans in A. niger. Bromov atom na hidrazonskem ligandu lahko poveča antibakterijsko aktivnost. 